\title{
Pharmacogenomics: The Promise of Personalized Medicine
}

Submitted: January 28, 2000; Accepted: February 21, 2000; Published: March 7, 2000.

Laviero Mancinelli ${ }^{1}$, Maureen Cronin ${ }^{1}$ and Wolfgang Sadée ${ }^{2}$

${ }^{1}$ ACLARA Biosciences, Inc., Santa Clara, CA 94043

${ }^{2}$ Department of Biopharmaceutical Sciences and Pharmaceutical Chemistry, University of California San Francisco, San Francisco, CA 94143-0446

ABSTRACT Pharmacogenetics and pharmacogenomics deal with the genetic basis underlying variable drug response in individual patients. The traditional pharmacogenetic approach relies on studying sequence variations in candidate genes suspected of affecting drug response. On the other hand, pharmacogenomic studies encompass the sum of all genes, i.e., the genome. Numerous genes may play a role in drug response and toxicity, introducing a daunting level of complexity into the search for candidate genes. The high speed and specificity associated with newly emerging genomic technologies enable the search for relevant genes and their variants to include the entire genome. These new technologies have essentially spawned a new discipline, termed pharmacogenomics, which seeks to identify the variant genes affecting the response to drugs in individual patients. Moreover, pharmacogenomic analysis can identify disease susceptibility genes representing potential new drug targets. All of this will lead to novel approaches in drug discovery, an individualized application of drug therapy, and new insights into disease prevention. Current concepts in drug therapy often attempt treatment of large patient populations as groups, irrespective of the potential for individual, genetically-based differences in drug response. In contrast, pharmacogenomics may help focus effective therapy on smaller patient subpopulations which although demonstrating the same disease phenotype are characterized by distinct genetic profiles. Whether and to what extent this individual, genetics-based approach to medicine results in improved, economically feasible therapy remain to be seen.

*Corresponding Author: Wolgang Sadee, Department of Biopharmaceutical Sciences and Pharmaceutical Chemistry, University of California San Francisco, San Francisco, CA 94143-0446; Telephone : (415) 476-1947; Facsimile: (415) 476-0464, E-mail: sadee@cgl.ucsf.edu
To exploit these opportunities in genetic medicine, novel technologies will be needed, legal and ethical questions must be clarified, health care professionals must be educated, and the public must be informed about the implications of genetic testing in drug therapy and disease management.

Key Words: Pharmacogenomics.

\section{Moving from "One Drug Fits All" to Personalized Therapy}

The 20th century has brought us a broad arsenal of therapies against all major diseases: infections, cardiovascular disease, neoplastic disease, and mental disorders. However, drug therapy often fails to be curative and may in fact cause substantial adverse effects. Moreover, worldwide use of these drugs has revealed substantial interindividual differences in therapeutic response. Any given drug can be therapeutic in some individuals but ineffective in others, and some individuals experience adverse drug effects whereas others are unaffected. Often, distinct molecular mechanisms underlie therapeutic and adverse effects.

Recognition of interindividual differences in drug response is an essential step towards optimizing therapy. Over the past decades, much evidence has emerged indicating that a substantial portion of variability in drug response is genetically determined, with age, nutrition, health status, environmental exposure, and concurrent therapy playing important contributory roles. To achieve individual drug therapy with a reasonably predictive outcome, one must further account for different patterns of drug response among geographically and ethnically distinct populations. 
These observations of highly variable drug response, which began in the early 1950 s, led to the birth of a new scientific discipline arising from the confluence of genetics, biochemistry, and pharmacology. Called pharmacogenetics, it focuses on drug response as a function of genetic differences among individuals. Applied to nontherapeutic foreign substances (xenobiotics), the equivalent term "toxicogenetics" is used.

Pharmacogenomics (or toxicogenomics) as a recently emerged discipline stems from the fusion of pharmacogenetics (or toxicogenomics) with genomics. Enabled by high-throughput technologies in DNA analysis, genomics introduces a further dimension to individualized predictive medicine. Determining an individual's unique genetic profile in respect to disease risk and drug response will have a profound impact on understanding the pathogenesis of disease, and it may enable truly personalized therapy. We can highlight this concept as "therapy with the right drug at the right dose in the right patient." Its urgency emerged in a recent survey of studies on adverse drug effects in hospitalized patients: adverse drug reactions may rank as the fifth leading cause of death in the United States ${ }^{1}$. Thus, we anticipate that pharmacogenomics will play an integral role in disease assessment, drug discovery and development, and selection of the type of drug. Moreover, it may provide information useful to the selection of dosage regimen for an individual patient.

Medicine, as we move into the third millennium, still targets therapy to the broadest patient population that might possibly benefit from it, and it relies on statistical analysis of this population's response for predicting therapeutic outcome in individual patients. Therapists of necessity make decisions about the choice of drug and appropriate dosage based on information derived from population averages. This "one drug fits all" approach could, with the fruits of pharmacogenomic research, evolve into an individualized approach to therapy where optimally effective drugs are matched to a patient's unique genetic profile ${ }^{2}$. This involves classifying patients with the same phenotypic disease profile into smaller subpopulations, defined by genetic variations associated with disease, drug response, or both. The assumption underlying this approach is that drug therapy in genetically defined subpopulations can be more efficacious and less toxic than in a broad population.

Individualizing drug therapy raises a number of issues with enormous practical consequences. Currently, the pharmaceutical industry is in a consolidation and merger phase, with ever larger corporations emerging at a steady pace. This consolidation is done in the expectation that many novel drugs can be brought to market with high efficacy against major diseases, driven by genomics-based drug discovery. Indeed, large corporations depend on generating "blockbuster" drugs-; drugs that raise in excess of a billion dollars in revenue each year by targeting large patient populations. However, it remains to be seen whether betting on a "one drug fits all" approach is realistic. Certainly, a few blockbuster drugs continue to emerge, for example, the Cox-2 selective inhibitors in the therapy of inflammatory joint diseases. Efficacy does not appear to exceed substantially that of traditional nonsteroidal antiinflammatory drugs (NSAIDs), which inhibit both Cox-1 and Cox-2 to varying degrees; however, the incidence of gastrointestinal lesions is reduced. Yet, only a portion of patients receiving conventional NSAIDs develop these lesions, and the traditional drugs are much less expensive. Moreover, it remains to be seen what long-term sequelae arise from treatment with Cox-2 selective inhibitors. These sequelae might be beneficial (for example, the possible prevention of colon cancer or neurodegenerative disorders associated with inflammation in the CNS), but the physiological functions of Cox-2 remain poorly understood. Trials over longer time periods will be needed to address these questions fully. As three quarters of all health care costs are used for the treatment of chronic illness, mostly of the aged, long-term issues will be the battleground where optimal therapies will be decided. 
Whether a single drug emerges superior to others in a broad patient population or whether best clinical response requires differential therapy of small subpopulations is the subject of fierce debates. Bringing a new drug to the market currently costs approximately $\$ 500$ million, making it economically impossible to target small patient populations. If smaller patient populations are to be served, we need to change the entire process, up to final regulatory agency approval for clinical use. Conceivably, targeting well-defined patient populations will sharpen our analysis of risk/benefit ratios and permit clinical trials to be substantially reduced in size. Laws and FDA regulations may have to be changed to accommodate the need for targeting patients with rare diseases or with subtypes of otherwise common diseases. This approach will set the stage for testing whether targeting small patient populations with select drugs is superior to treating many patients with the best drug available for a given disease. The outcome may vary from one case to another.

Thus, individualizing drug therapy with the use of pharmacogenomics holds the potential to revolutionize medical therapeutics, by challenging the "one drug fits all" approach. Furthermore, pharmacogenomics could also enhance the value of currently approved drugs with limited market share because of significant toxicity or limited efficacy, enabling prescribers to identify patients for whom they will be both effective and safe.

\section{Historical Perspective: Pharmacogenetics}

Biologists have long accepted that the capacity of organisms to respond differently to their environment is genetically determined ${ }^{3}$. Investigations into human physiology and chemistry during the mid-19th century, accelerated by the emergence of organic chemistry, established that ingested chemicals are excreted in a different form. These early metabolic studies fell into the period between the discovery of the laws of genetics by
Gregor Mendel in 1865 and their rediscovery around the turn of the century.

Two separate investigators, Lucien Cuenot, working with coat colors in mice, and his contemporary, Archibald Garrod, studying alcaptonuria in humans, anticipated the connection between enzymes and genes. Garrod's work on alcaptonuria in 1902 constituted the first proof of Mendelian genetics in humans. As a result of these studies, he advanced the hypothesis that genetically determined differences in biochemical processes could be the cause of adverse reactions after the ingestion of drugs $^{4}$. Remarkably, Garrod went as far as to suggest that enzymes were implicated in the detoxification of foreign substances, and that such a mechanism might fail in some persons for lack of the required detoxifying enzyme ${ }^{4}$. These studies on alkaptonuria are the basis for the development of biochemical genetics and biochemical pharmacology. Moreover, this research presaged our current concept of genetically controlled interindividual variation in the response to foreign substances.

The first complete report of an inherited difference in the response to a foreign chemical or xenobiotic described inability to taste phenylthiocarbamide (PTC). In 1932, Snyder demonstrated that this "taste blindness" was inherited as an autosomal recessive Mendelian trait ${ }^{5}$. This and other defects in sensory perception related to xenobiotic exposure were the first known examples of genetic polymorphism, a concept introduced some years later by Ford ${ }^{6}$. The molecular basis of "taste blindness" to PTC has never been confirmed, but the report is widely regarded as the first example of a pharmacogenetic study ${ }^{7}$.

Garrod's original hypothesis was buttressed when it was noticed during World War II that "primaquine hemolysis" was much more common among African-American soldiers in the United States Army who were taking the antimalarial primaquine $^{8}$. Subsequent study in the postwar period revealed that the cause of this drug-induced 
hemolysis was a genetic deficiency of glucose-6phosphate dehydrogenase (G-6-PD) ${ }^{9}$.

Evidence of interindividual variations in the response to suxamethonium (succinylcholine), isoniazid, and debrisoquine was also scrutinized for a genetic connection. Clinical reports first surfaced in the late 1940s of peripheral neuropathy occurring in a substantial number of patients treated with the antituberculosis drug isoniazid ${ }^{10}$. These initial clinical observations were followed by the realization that slow metabolizers (acetylators), although frequencies varied, followed defined geographic and ethnic population distributions ${ }^{11}$. We now know that the "slow acetylator phenotype" represents approximately $40 \%$ to $60 \%$ of Caucasians and results in slow clearance and the potential for associated toxicity from drugs such as isoniazid, procainamide, and phenelzine ${ }^{12}$. Initial clinical trials of suxamethonium in small numbers of patients gave no indication of complications or toxicity. However alarming reports of prolonged apnea following clinical doses of suxamethonium appeared in large-scale trials of the new muscle relaxant. Subsequent investigation suggested that a deficiency in the metabolizing enzyme (pseudocholinesterase), possibly of hereditary origin, was responsible. These person-to-person variations in response to primaquine, followed by isoniazid and suxamethonium, were the first to be studied from a genetic perspective. Following in the wake of these initial observations, Arno Motulsky proposed in 1957 that the inheritance of acquired traits might explain many individual differences, both in the efficacy of drugs and in the occurrence of adverse drug reactions ${ }^{13}$.

A serendipitous observation by physicians at St. Mary's Hospital Medical School in London (that a volunteer's severe hypotensive response in a clinical trial with debrisoquine was due to impaired oxidative metabolism) led to the identification of yet another important, genetically determined variation in drug response. At the same time, German physicians independently observed greatly exaggerated adverse drug effects in some patients administered the alkaloid sparteine, which has antiarrhythmic properties. This reaction was also attributed to decreased oxidative metabolism ${ }^{14}$. Family studies revealed that the metabolism of both drugs is under monogenic control and that poor metabolizers are homozygous for a recessive allele of cytochrome P450, now termed CYP2D6, or debrisoquine 4-hydroxylase.

These observations and the subsequent research inspired by them have helped to lay the foundation for pharmacogenetics. Today, many examples of variability in both drug response and toxicity associated with known genetic variability are documented (Table 1). In a few cases, genetic tests are beginning to find their way into clinical practice, making a proactive approach to individualized therapy possible. In cancer chemotherapy of acute lymphocytic leukemia, administration of drugs such as 6-mercaptopurine, 6-thioguanine, and azathioprine can cause severe hematologic toxicity or even death in patients possessing nonfunctional ("null") variants of thiopurine methyltransferase (TPMT). Functional assays of TPMT in red blood cells, or alternatively genotyping, can identify those patients (approximately 1 in 300) who are homozygous for alleles encoding nonfunctional enzyme, and therefore unable to metabolize the drugs to their inactive methylated forms. These patients can be safely treated with doses 10 to 15 times less than commonly prescribed ${ }^{15,16}$. Therefore, genotyping, or functional enzyme analysis, has become standard practice in major cancer treatment centers such as the Mayo Clinic (Rochester, MN) and St. Jude's Children Research Hospital (Memphis, TN).

Pharmacogenetics applies not only to traditional drugs but also to bioengineered proteins and gene therapy. Human genetic variability can be expected to affect all treatment modalities. For example, breast cancer treatment with trastuzumab (Herceptin), a humanized monoclonal antibody against the HER2 receptor developed by Genentech, Inc., is linked to HER2 overexpression. This reaction correlates with poor clinical prognosis and serves as a marker for responsiveness to 
Table 1 -Examples of inherited or acquired variations in enzymes and receptors that affect drug response (adapted from 29, 30, 39).

\begin{tabular}{|c|c|c|c|}
\hline Enzyme & Variant Phenotypes & Drugs & Modified Response \\
\hline $\begin{array}{l}\text { Pl asma } \\
\text { p seudocholinesterase }\end{array}$ & Slow ester hydrolysis & Succinylcholine & Prolonged apnea \\
\hline $\begin{array}{l}\text { Acetyl transferease } \\
\text { NAT2 }\end{array}$ & Slow, rapid acetyl ators & $\begin{array}{l}\text { Isoniazid } \\
\text { Sul famethazine } \\
\text { Procainamide } \\
\text { Dapsone } \\
\text { Sufasalazine } \\
\text { Paraminosalicylic acid } \\
\text { Heterocyclic amines } \\
\text { (food mutagens) }\end{array}$ & $\begin{array}{l}\text { Slow. toxic neuritis, } \\
\text { lupus erythematosus } \\
\text { disease susceptibility, } \\
\text { bladder cancer } \\
\text { Rapid: colorectal cancer }\end{array}$ \\
\hline $\begin{array}{l}\text { Thiopurine } \\
\text { methyltransferase }\end{array}$ & Poor TPMT methylators & $\begin{array}{l}\text { 6-Mercaptopurine } \\
\text { 6-Thioguanine } \\
\text { Azathioptin }\end{array}$ & $\begin{array}{l}\text { Bone marow toxcicity, } \\
\text { liver damage }\end{array}$ \\
\hline $\begin{array}{l}\text { Dihy dropyrimidine } \\
\text { dehydrogenase }\end{array}$ & Slow inactivation & 5-Fluorouracil & $\begin{array}{l}\text { Possible enhanced } \\
\text { toxicity }\end{array}$ \\
\hline $\begin{array}{l}\text { Aldehyde } \\
\text { dehydrogenase, ALDH2 }\end{array}$ & Fast, slow metabolizers & Ethanol & $\begin{array}{l}\text { Slow. facial flushing } \\
\text { Fast: protection from } \\
\text { liver cirhosis }\end{array}$ \\
\hline $\begin{array}{l}\text { Catechol O-methyl } \\
\text { transferease }\end{array}$ & $\begin{array}{l}\text { Levodopa } \\
\text { Methyl dopa }\end{array}$ & High, low methylators & Low. increased response \\
\hline CYP 2D6 & $\begin{array}{l}\text { Ultra rapid* } \\
\text { Extensive* } \\
\text { Poor metabolizers }\end{array}$ & $\begin{array}{l}\text { Debrisoquine Spattein } \\
\text { Phen formin } \\
\text { Nortryptilin } \\
\text { Dextromorphan, etc }\end{array}$ & $\begin{array}{l}\text { Poor: increased toxicity } \\
\text { Extensive: lung cancer? } \\
\text { Rapid: drug resistance }\end{array}$ \\
\hline CYP 2C9 & Poor metabolizers & $\begin{array}{l}\text { Tolbutamide, S- } \\
\text { warfarin, Phenytoin } \\
\text { nonsteroidal anti- } \\
\text { infl ammatory agents, } \\
\text { imi pramine }\end{array}$ & $\begin{array}{l}\text { Increased response or } \\
\text { toxicity }\end{array}$ \\
\hline CYP 2C19 & $\begin{array}{l}\text { Poor, extensive } \\
\text { hydroxylators }\end{array}$ & $\begin{array}{l}\text { Mephenytoin } \\
\text { Hexobarbital } \\
\text { Omeprazole } \\
\text { Proguanil, etc }\end{array}$ & $\begin{array}{l}\text { Poor: increased toxicity; } \\
\text { poor efficacy } \\
\text { (proguanil) }\end{array}$ \\
\hline \multicolumn{4}{|l|}{ Receptors } \\
\hline$\beta_{2}$ Adrenoceptor & $\begin{array}{l}\text { Enhanced receptor } \\
\text { downregulation }\end{array}$ & $\begin{array}{l}\text { Albuterol } \\
\text { Ventolin }\end{array}$ & Poor control of asthma \\
\hline $\begin{array}{l}\text { 5-HT2A Serotonergic } \\
\text { receptor }\end{array}$ & Multiple polymorphisms & Clozapine & $\begin{array}{l}\text { Associated with variable } \\
\text { drug efficacy }\end{array}$ \\
\hline HER2 & $\begin{array}{l}\text { Overexpression in breast } \\
\text { and other cancers }\end{array}$ & $\begin{array}{l}\text { Trastuzumab } \\
\text { (Herceptin) }\end{array}$ & $\begin{array}{l}\text { Overexpression } \\
\text { associated with } \\
\text { therapeutic efficacy }\end{array}$ \\
\hline \multicolumn{4}{|l|}{ Transporters } \\
\hline $\begin{array}{l}\text { Multiple drug resistance } \\
\text { transporter }\end{array}$ & Overexpression in cancer & $\begin{array}{l}\text { Vinblastin } \\
\text { Doxorubicin } \\
\text { Paclitaxel, etc }\end{array}$ & Drug resi stance \\
\hline
\end{tabular}

*Hyperactivity can result from activating mutations or gene duplications. 
trastuzumab therapy, either alone or in combination with chemotherapy ${ }^{17,18}$.

\section{Cytochrome P450}

The cytochrome P450 monooxygenase system of enzymes is responsible for a major portion of drug metabolism in humans. Although commonly serving to detoxify xenobiotics, these enzymes are also principally responsible for the activation of procarcinogens and promutagens in the human body. This scenario is particularly important for lipophilic drugs such as CNS-active drugs, which generally must be lipophilic to penetrate the bloodbrain barrier. Because renal excretion is minimal for these compounds, P450 metabolism provides the primary means of drug elimination. This large family of genes has been intensely studied, and among the numerous P450 subtypes, CYP2D6, $3 \mathrm{~A} 4 / 3 \mathrm{~A} 5, \quad 1 \mathrm{~A} 2,2 \mathrm{E} 1,2 \mathrm{C} 9$, and 2C19 play particularly critical roles in genetically determined responses to a broad spectrum of drugs.

Patients who are homozygous for the CYP2D6 null alleles exhibit a poor metabolizer phenotype, with impaired degradation and excretion of many drugs, including debrisoquine, metoprolol, nortriptyline, and propafone ${ }^{19}$. These poor metabolizers are more likely to exhibit adverse drug reactions. The frequency of this recessive trait ranges from $1 \%$ to $2 \%$ in Asians, to approximately $5 \%$ in African Americans, to $6 \%$ to $10 \%$ in Caucasian populations ${ }^{20}$. More than 40 drugs used in clinical practice, especially in the areas of cardiovascular disease $^{21}$ and psychiatric disorders ${ }^{22}$, have now been identified for which metabolism follows the same pattern as debrisoquine and sparteine. Determination of a patient's CYP2D6 phenotype/genotype may prove useful in treatment with antipsychotic drugs ${ }^{23}$, while comprehensive genotyping assays for all relevant P450 isotypes and their main sequence variants are being developed.

Similarly, patients who are homozygous for the "null" allele of the P450 isoform CYP2C19 are highly sensitive to omeprazole, diazepam, propranolol, mephenytoin, amitriptyline, hexobarbital and other drugs ${ }^{19}$. The CYP2C19 poor metabolizer phenotype comprises $2 \%$ to $5 \%$ of Caucasians and $3 \%$ to $23 \%$ of Asians, resulting largely from a single base pair mutation $(A \rightarrow G)$ in exon 5 of the coding region 7 . The truncated mutant protein lacks the heme-binding region and is enzymatically inert ${ }^{24}$.

Another polymorphically expressed member of the cytochrome P450 family, CYP2C9, metabolizes a range of therapeutically important drugs such as ibuprofen, naproxen, piroxicam, tetrahydrocannabinol, phenytoin, tolbutamide, and S-warfarin $^{25}$. A number of these substrates have narrow therapeutic indices; therefore, this genetic variation has clinical significance. Amino acid substitutions at codons 144 and 359 in the coding region of $C Y P 2 C 9$ result in a 5-fold decline in metabolic activity. Although the frequency of these 2 allelic variants is uncertain, approximately $25 \%$ of Caucasians appear to be heterozygous for one or the other variant, leading to a predicted frequency of $5 \%$ for the homozygous genotype ${ }^{26}$.

Including genotype effects in screening new drug candidates may help to avoid potential adverse effects caused by such polymorphisms relevant to drug action. Five years ago, 53\% of surveyed pharmaceutical companies indicated that they screen drug candidates during the lead discovery phase to determine whether they are metabolized by P450 cytochromes for which significant polymorphism is known to exist. The figure today approaches $80 \%{ }^{27}$.

Cytochrome P450s inactivate or in some cases activate xenobiotics. Therefore, P450 polymorphisms affect an individual's susceptibility to environmental toxins. As a result, sequence variation of P450 isotypes attracts special attention in toxicogenetics. Recently the US National Institute of Environmental Health Sciences launched the Environmental Genome Project with 
the stated goal of understanding the genetic factors governing an individual's response to the environment on a genome-wide scale. This effort parallels the study of genetic variability in drug response ${ }^{28}$.

\section{Pharmacogenomics}

Pharmacogenomics is an emerging discipline critical for assessing the genetic basis of drug response and toxicity in targeted patient populations $^{29}$. By broadening the search for genetic factors affecting drug response, pharmacogenomics is beginning to supersede the candidate gene approach typical of earlier pharmacogenetic studies. Pharmacogenetics incorporates the disciplines of biochemistry and pharmacology and seeks to correlate phenotypic biomarkers, such as drug induced toxicity, with genetic characterization by association studies and twin studies in patients. Pharmacogenomics, on the other hand, takes advantage of genomic techniques such as highthroughput DNA sequencing, gene mapping, and bioinformatics to allow researchers to identify the actual genetic basis of interindividual and interracial variation in drug efficacy, metabolism, and transport. Each drug after it enters the body interacts with numerous proteins, such as carrier proteins, transporters, metabolizing enzymes, and multiple types of receptors ${ }^{2,} 30,31$. These proteins determine drug absorption, distribution, excretion, target site of action, and pharmacological response. Moreover, drugs trigger downstream secondary events that may also vary among patients. As a result, multiple polymorphisms in many genes may affect drug response, requiring a genome-wide search for the responsible genes.

Profiling the expression pattern of genes in a target tissue reveals mechanisms of drug action in a genomic context, and it can serve to clarify interindividual differences in drug response that are downstream of immediate drug effects in the body. Analyzing the entire transcriptional program of a tissue, for example, fibroblasts in response to serum stimulation $^{32}$, has revealed unprecedented detail of a complex response. Tissue transcript profiling is especially appropriate in cancers with inherent genetic instability because mRNA can be extracted from biopsies or surgical samples. Altered gene expression in the tumor can serve as a guide for selecting effective drug therapy or avoiding unnecessary exposure to toxic but ineffective drugs (Table 1).

The Human Genome Project (HGP) and advanced technology spin-offs emanating from it will have a profound impact on drug discovery, development, and therapy within the pharmaceutical industry ${ }^{33}$. Innovative automated instrumentation, new analytical and informatics approaches, and novel strategies emerging from genome-based research will be essential for exploiting the massive primary sequence data. Technical innovations such as DNA microarrays and microfluidic analytical devices are revolutionizing the biological sciences by enabling economy of scale for high-throughput DNA sequencing and gene mapping required for genomic research.

DNA microarrays, although they can be assembled by one of several methods, all have a common origin in the DNA blotting methods pioneered by Southern in the early 1970s. The common elements of this approach to nucleic acid analysis are an immobilized or tethered nucleic acid (DNA or RNA) species that is hybridized with a second, solution-phase DNA or RNA species that is generally labeled with a detectable molecule such as a fluorescent dye. The sequence of the unknown "target" nucleic acid is determined by decoding its complementarity with the nucleic acid "probe" of known sequence. Whether the probe or target nucleic acid is immobilized varies among the different array methods, but most commonly, the "probe" is tethered to a surface and the target to be analyzed is in solution.

Lab card or lab-on-a-chip devices are becoming increasingly important in genomic analysis. Microcapillary electrophoresis separation devices pioneered fewer than 10 years ago by Harrison, Ramsay, Mathies, and others have virtually replaced traditional gel electrophoresis for high-throughput 
sequencing ${ }^{34,35}$. Lab cards with complex networks of microcapillary channels finer than human hair have now been demonstrated to be useful not only for molecular separations but also to carry out nanoscale biochemical reactions. Polymerase chain reactions, sequencing reactions, primer extension reactions, and nuclease cleavage reactions carried out in these devices realize an order of magnitude improvement in throughput and economy over microtitre plate-;based biochemistry. Increasingly simple and inexpensive genetic testing systems based on high-throughput DNA microarrays and microfluidic devices should eventually allow patients to be prescreened for specific, relevant polymorphisms before drug therapy is initiated ${ }^{36}$.

Genomic techniques are making it possible not only to identify tangible new gene targets for drug discovery efforts, but also to find associations between specific genetic markers and drug response in a patient population. An evolving key element in genome-wide searches for genes relevant to disease and therapy is a comprehensive map of polymorphisms distributed over the entire genome. Polymorphisms are generally defined as variations in DNA sequence that occur in at least $1 \%$ of the population. The vast majority of polymorphisms are single nucleotide polymorphisms, or SNPs (pronounced "snips"). Because the human genome contains 3 billion nucleotides, and variations between individuals occur approximately once in each 300 base pairs, approximately 10 million SNPs are expected to exist between any 2 genomes. Because only a fraction of these SNPs are likely to prove relevant to a drug response, the ultimate goal will be to identify all functionally important variants, truly a Herculean task.

Major pharmaceutical firms have responded to the growing emphasis on individualized therapy to improve drug efficacy and safety with large investments in pharmacogenomics research (Table 2). It is becoming apparent that genetic testing to identify patients in whom a particular drug can be given safely and effectively may provide those products with a competitive advantage. Several of the world's largest pharmaceutical firms, including
AstraZeneca, Bayer, Pfizer, SmithKline Beecham, and Novartis have formed a consortium with 5 major academic centers with the goal of identifying 300,000 heritable SNPs within the next 2 years ${ }^{37}$. The National Institutes of Health, in an independent effort, has made $\$ 30$ million available over 3 years, starting in January of 1998, for the discovery and compilation of $100,000 \mathrm{SNPs}^{37}$. To top this all, scientists at Celera Genomics contend that they will have a collection of 6 to 10 million SNPs by mid 2000. With availability of high-resolution SNP maps and DNA microarray analytical capability, performing genome-wide association studies during clinical trials becomes feasible, enabling one to identify disease-susceptibility genes for prognosis, drug discovery, and selection of therapy. If risk for a given disease is predicted to be high, as judged by the SNP pattern of a patient, preventive therapy and lifestyle adjustments (diet, exercise, etc) may be implemented. A comprehensive SNP map will also contain genetic variants relevant to drug transport, metabolism, and receptor interaction and, therefore, needs to be considered in drug selection. Moreover, a comprehensive SNP map may also serve to alert the therapist when careful drug dosage monitoring is required. Stratifying patient populations using genome-wide SNP maps presents a major challenge to the pharmaceutical industry. The outcome from applying such an approach cannot be accurately gauged at present.

Relevant websites with information on pharmacogenomic issues are summarized in Table 3.

\section{What Do We Learn From Pharmacogenomics About Future Potential and Limits of Drug Therapy?}

Genetic heterogeneity appears to be a significant source of variability observed in the response to drugs. This variability means that information pertaining to interethnic and interindividual genetic differences can be used to facilitate rational drug discovery and development and to avoid or minimize the incidence of adverse events in clinical trials. Thus, one could generate criteria for selecting 
Table 2 - Selected Companies With a Focus on Genomics, Including Pharmacogenomics.

\begin{tabular}{|c|c|c|}
\hline Company & Web Address & Focus \\
\hline $\begin{array}{l}\text { ACLARA } \\
\text { BioSciences, Inc }\end{array}$ & http://www.aclara.com & Lab card microfluidic technology \\
\hline $\begin{array}{l}\text { Aeiveos Sciences } \\
\text { Group, LLC }\end{array}$ & www.aeiveos.com & $\begin{array}{l}\text { Aging-related genes and gene } \\
\text { responses }\end{array}$ \\
\hline Affymetrix, Inc & http://www.affymetrix.com & GeneChip microarray technology \\
\hline $\begin{array}{l}\text { Aurora Bioscience } \\
\text { Corp }\end{array}$ & http://www.aurorabio.com & $\begin{array}{l}\text { Genomic and drug screening } \\
\text { technology }\end{array}$ \\
\hline $\begin{array}{l}\text { Axys Pharmaceuticals } \\
\text { Inc./PPGx }\end{array}$ & http://www.axyspharm.com & $\begin{array}{l}\text { Pharmacogenomics (with PDD } \\
\text { Inc.) }\end{array}$ \\
\hline $\begin{array}{l}\text { Caliper Technologies } \\
\text { Corp }\end{array}$ & http://www.clipertech.com & $\begin{array}{l}\text { Microfluidic Lab Chip, SNP } \\
\text { scanning (with Agilent) }\end{array}$ \\
\hline Celera Genomics & http://www.celera.com & $\begin{array}{l}\text { Human Genome sequencing and } \\
\text { SNP scanning }\end{array}$ \\
\hline Cellomics, Inc & Www.cellomics.com/ & $\begin{array}{l}\text { Pharmacocellomics, cellular } \\
\text { bioinformatics }\end{array}$ \\
\hline Curagen Corp & http://www.curagen.com/ & $\begin{array}{l}\text { SNP scanning; Gene expression } \\
\text { and drug response }\end{array}$ \\
\hline DxS Ltd & http://www.dxsgenotyping.com/ & Pharmacogenomic services \\
\hline Epidauros & http://www.epidauros.com/ & $\begin{array}{l}\text { Pharmacogenomics in drug } \\
\text { discovery and therapy }\end{array}$ \\
\hline Exelixis, Inc & http://www.exelixis.com & $\begin{array}{l}\text { Model systems for drug } \\
\text { discovery }\end{array}$ \\
\hline Eurona Medical, AB & http://www.eurona.com/ & $\begin{array}{l}\text { Drug responses and genetic } \\
\text { profiling }\end{array}$ \\
\hline Gemini Research, Ltd & http://www.gemini-research.co.uk/ & $\begin{array}{l}\text { Gene discovery; dizygotic twin } \\
\text { studies }\end{array}$ \\
\hline $\begin{array}{l}\text { Genaissance } \\
\text { Pharmaceuticals, Inc }\end{array}$ & http://www.genaissance.com & $\begin{array}{l}\text { Genetic polymorphism in cancer, } \\
\text { vascular lesions }\end{array}$ \\
\hline Gene Logic, Inc & http://www.genelogic.com & Gene expression databases \\
\hline $\begin{array}{l}\text { Genome Therapeutics } \\
\text { Corp }\end{array}$ & http://www.crik.com/ & $\begin{array}{l}\text { Human high-resolution } \\
\text { polymorphism database }\end{array}$ \\
\hline Genometrix, Inc & http://www.genometrix.com & DNA microarrays \\
\hline $\begin{array}{l}\text { Genomic Solutions, } \\
\text { Inc }\end{array}$ & http://www.genomesolutions.com/ & Genomics \\
\hline Genset, SA & http://www.genset.fr & $\begin{array}{l}\text { High-density biallelic maps; SNP } \\
\text { identification }\end{array}$ \\
\hline Hexagen Pic & http://www.hexagen.co.uk/ & $\begin{array}{l}\text { Single-strand conformational } \\
\text { assay of polymorphisms }\end{array}$ \\
\hline Hyseq, Inc & http://www.hyseq.com & $\begin{array}{l}\text { Genomic methods for therapeutic } \\
\text { discovery }\end{array}$ \\
\hline $\begin{array}{l}\text { Incyte } \\
\text { Pharmaceuticals, Inc }\end{array}$ & http://www.incyte.com & $\begin{array}{l}\text { Bioinformatics, SNP scanning, } \\
\text { functional genomics }\end{array}$ \\
\hline Kiva Genetics & http://www.kivagen.com & Pharmacogenetic testing services \\
\hline
\end{tabular}


AAPS PharmSci 2000; 2 (1) Article 4 (http://www.aapspharmsci.org/)

\begin{tabular}{|c|c|c|}
\hline Lion Bioscience, AG & http://www.lion-ag.de/ & $\begin{array}{l}\text { Bioinformatics, drug targets from } \\
\text { gene expression }\end{array}$ \\
\hline Lynx Therapeutics & http://www.lynxgen.com & $\begin{array}{l}\text { Micro-bead based DNA/SNP } \\
\text { scanning }\end{array}$ \\
\hline $\begin{array}{l}\text { Microcide } \\
\text { Pharmaceuticals }\end{array}$ & http://www.microcide.com/ & $\begin{array}{l}\text { Microbial genomics and } \\
\text { antibiotics }\end{array}$ \\
\hline Mitokor, Inc & http://www.mitokor.com/ & Mitochondrial genome analysis \\
\hline Nova Molecular, Inc & http://www.cns-hts.com/ & CNS disease profiling \\
\hline $\begin{array}{l}\text { Millennium Predictive } \\
\text { Medicine }\end{array}$ & subsid/mpmx.html & $\begin{array}{l}1 \text { Pharmacogenomics, predicting } \\
\text { disease and therapy }\end{array}$ \\
\hline $\begin{array}{l}\text { Orchid Biocomputer, } \\
\text { Inc }\end{array}$ & http://www.orchidbio.com & $\begin{array}{l}\text { Microfluidic devices and } \\
\text { pharmacogenetic testing }\end{array}$ \\
\hline PE Biosystems, Inc & http://www.pebio.com & Genomics, drug discovery \\
\hline PPGx & http://www.ppgx.com & $\begin{array}{l}\text { Pharmacogenetic Testing } \\
\text { Services }\end{array}$ \\
\hline $\begin{array}{l}\text { Protogene } \\
\text { Laboratories }\end{array}$ & http://www.protogene.com & DNA microarray development \\
\hline Rigel, Inc & http://www.rigelinc.com/ & $\begin{array}{l}\text { Identification of genetic drug } \\
\text { targets }\end{array}$ \\
\hline Rosetta Inpharmatics & http://www.rii.com/ & Oligonucleotide array studies \\
\hline $\begin{array}{l}\text { Third Wave } \\
\text { Technologies, Inc }\end{array}$ & http://www.twt.com/ & $\begin{array}{l}\text { SNP scanning, } \\
\text { pharmacogenomics }\end{array}$ \\
\hline Transgenomic, Inc & http://www.transgenomic.com/ & Discovery of genetic variations \\
\hline Variagenics, Inc & http://www.variagenics.com/ & $\begin{array}{l}\text { Cancer therapeutics based on loss } \\
\text { of heterozygosity }\end{array}$ \\
\hline
\end{tabular}

patients most likely to benefit from a drug without incurring unnecessary risk. Early or preventive therapy guided by genotyping could significantly enhance clinical outcome. The need for a new, individualized approach to drug development and therapy is clear. Every year, approximately 3.1 billion prescriptions are issued in the United States, of which approximately 2.1 million result in an adverse reaction. One million prescriptions from this latter group may result in hospitalization, and of these more than 100,000 patients may $\mathrm{die}^{38}$.

How can we reduce these severe adverse reactions by using pharmacogenomics? Over the near term, patient genotyping prior to therapy in a few but increasing number of instances will serve to avert or minimize severe drug toxicity. Alternatively, drugs may be designed a priori so that they are not subject to the differential metabolic patterns known to be caused by polymorphic variation.

Looking farther ahead, and on a much broader scale, the efficacy of administered drugs may be improved, rather than avoiding toxicity as the main objective, by distinguishing good responders from poor responders prior to therapy. Often, effective drug response is limited to a portion of treated patients, whereas the majority benefits little or not at all. Predicting which patients are most likely to respond best to a particular drug, or which drug will yield optimal effects for a given patient, would represent a significant advance in therapy even with current drugs, let alone novel drugs developed with these criteria in mind. The success of this approach 
Table 3 - Web Sites Containing Pharmacogenomics Information.

\begin{tabular}{|l|l|}
\hline Description & URL \\
\hline & \\
\hline Human Genome Project (HGP) & http://www.ornl.gov/TechResources/Human_Genome/home.html \\
\hline $\begin{array}{l}\text { Glossary of Genetic Terms } \\
\text { (NIH) }\end{array}$ & http://www.nhgri.nih.gov/DIR/VIP/Glossary \\
\hline $\begin{array}{l}\text { Primer on Molecular Genetics } \\
\text { (JHMI) }\end{array}$ & http://www.bis.med.jhmi.edu.Dan/DOE/intro.html \\
\hline $\begin{array}{l}\text { Environmental Genome SNP } \\
\text { Database and Research } \\
\text { Platform }\end{array}$ & http://dir.niehs.nib.gov/egsnp/status \\
\hline $\begin{array}{l}\text { National Center for } \\
\text { Biotechnology Information }\end{array}$ & http://www.ncbi.nlm.nih.gov/SNP \\
\hline $\begin{array}{l}\text { Orchid Biocomputer } \\
\text { maintained SNP site }\end{array}$ & http://www.snps.com \\
\hline $\begin{array}{l}\text { Stanford University Genome } \\
\text { Resources }\end{array}$ & http://www-genome.stanford.edu/index.html \\
\hline Weizmann Institute & http://bioinfo.weizmann.ac.il \\
\hline $\begin{array}{l}\text { Whitehead Institute for } \\
\text { Biomedical Research }\end{array}$ & http://www-genome.wi.mit.edu \\
\hline Genset, Inc, site & http://www.genxy.com/Science/index.html \\
\hline SNP Consortium site & http://snp.cshl.org \\
\hline $\begin{array}{l}\text { Human genic bi-allelic } \\
\text { sequence database }\end{array}$ & http://hgbase.interactiva.de \\
\hline
\end{tabular}

depends in large part on assembling an extensive, high-quality database of informative SNPs, a major focus for genomics companies (Table 2). Ultimately the vision of pharmacogenomics encompasses a genetic profile for each individual, containing sufficient information to select which drugs are most likely to be safe and effective in that person. The same insight will serve to prevent disease to begin with, arguably the most desirable goal.

However, obstacles to the implementation of this vision are formidable. The dynamic complexity of the human genome, multigenic disease origins, and involvement of numerous genes in drug response impede the effective application of genome-wide SNP scanning in the clinic. Drug responses will most likely be associated with patterns of multiple polymorphically expressed traits, rather than single causative polymorphisms. Such patterns of genetic variants differ among distinct ethnic groups. This factor could obscure prediction of disease susceptibility and drug response across patient populations, and it points to the need to genetically stratify patients for clinical pharmacogenomic studies.

We are uncertain as to the overall direction of pharmacogenomics over the next 10 years. Although new analytical systems introduced during the last decade have offered incremental improvements over previously available technology, they have not allowed scientists to maximize the benefit of multiple advancements in genomics, combinatorial chemistry, and assay technologies. The realization of an individualized approach to drug discovery and therapy will require 
new statistical methods and analytical systems providing an order-of-magnitude increase in throughput, along with corresponding decreases in operating costs, with enhanced accuracy and reduced complexity.

In addition to the daunting scientific challenges we have outlined, ethical issues need to be resolved. Information about an individual's genetic makeup raises privacy questions and ethical dilemmas about disease susceptibility, prognosis, and treatment options. Obviously, information of this type must be carefully safeguarded to ensure privacy. Many legal and economic issues will need to be resolved.

Whether or not these new genomic technologies find their way into everyday clinical use during the next 10 years, they will prove valuable tools in clinical research directed at optimizing drug therapy. The vision of pharmacogenomics is leading us to a more individualized approach to drug therapy, while revealing limits inherent to the treatment of disease in broad patient populations.

\section{REFERENCES}

1. Lazarou J, Pomeranz BH, Corey PN. Incidence of adverse drug reactions in hospitalized patients. JAMA. 1998;279:12001205 .

2. Sadee W. Finding the right drug for the right patient. Pharm Res. 1998;15:959-963.

3. Maynard Smith J. The Theory of Evolution. Baltimore, Maryland: Penguin Books; 1962.

4. Garrod AE. The incidence of alcaptonuria: a study in chemical individuality. Lancet. 1902;ii:1616-1620.

5. Snyder LH. Studies in human inheritance. Ohio J Sci. 1932;32:436-468.

6. Ford EB. Genetic Polymorphism. London: Faber \& Faber; 1965.

7. Nebert DW. Pharmacogenetics: 65 candles on the cake. Pharmacogenetics. 1997;7:435-440.

8. Kalow W. Pharmacogenetics: heredity and the response to drugs. Philadelphia: W. B. Saunders; 1962.

9. Carsen PE, Flanagan CL, Iokes CE, Alving AS. Enzymatic deficiency in primaquine-sensitive erythrocytes. Science. $1956 ; 124,484-485$.
10. Hughes HB, Biehl JP, Jones AP, Schmidt, LH. Metabolism of isoniazid in man as related to the occurrence of peripheral neuritis. Am Rev Tuberculosis. 1954;70:266-273.

11. Evans DAP, Manley KA, McKusick VA. Genetic control of isoniazid metabolism in man. Br Med J. 1960;2:485-490.

12. Vatsis K, Martell KJ, Weber WW. Proc Natl Acad Sci U S A. 1991;88:6333.

13. Motulsky AG. Drug reactions, enzymes and biochemical genetics. JAMA. 1957;165:835-837.

14. Eichelbaum M, Steincke B, Dengler JJ. Defective Noxidation of sparteine in man: a new pharmacogenetic defect. Eur J Clin Pharmacol. 1977;16:183-187.

15. Weinshilboum RM, Sladek SL. Mercaptopurine pharmacogenetics: monogenic inheritance of erythrocyte thiopurine methyltransferase activity. Am J Hum Genet.1980;32:651-62.

16. Tai H, Krynetski EY, Yates CR, et al. Thiopurine Smethyltransferase deficiency: two nucleotide transitions define the most prevalent mutant allele associated with loss of catalytic activity in Caucasians. Am J Hum Genet. 1996;58:694-702.

17. Goldenberg MM. Trastuzumab, a recombinant DNA derived humanized monoclonal antibody, a novel agent for the treatment of metastatic breast cancer. Clin Therapeut. 1999;21:309-318.

18. Baselge J, Norton L, Albanell J, Kim YM, Mendelsohn J. Recombinant humanized anti-HER2 antibody (HERCEPTIN) enhances the antitumor activity of paclitaxel and doxorubicin against HER2/neu overexpressing human breast cancer xenografts. Cancer Res. 1998;58:2825-2831.

19. Touw DJ. Clinical implications of genetic polymorphisms and drug interactions mediated by cytochrome P450 enzymes. Drug Metab Drug Interact. 1997;14:55-82.

20. Evans DAP. Genetic factors in drug therapy. In: Clinical and Molecular Pharmacogenetics. Cambridge: Cambridge University Press; 1993.

21. Buchert E, Woosley RL. Clinical implications of variable antiarrythmic drug metabolism. Pharmacogenet. 1992;2:2-11.

22. Dahl AK, Bertilsson, L. Genetically variable metabolism of antidepressants and neuroleptic drugs in man. Pharmacogenet. 1993;3:61-70.

23. Tanaka E, Hisawa S. Clinically significant pharmacokinetic drug interactions with psychoactive drugs: antidepressants and antipsychotics and the cytochrome P450 system. J Clin Pharm Ther. 1999;24:7-16

24. de Morais S, Wilkinson GR, Blaisdell J, Nakamura K, Meyer UA, Goldstein JA. The major genetic defect responsible for the polymorphism of S-mephenytoin metabolism in humans. $J$ Biol Chem 1994,269:15419-15422.

25. Daly AK. Molecular basis of polymorphic drug metabolism. J Mol Med. 1995;73:39-553. 
AAPS PharmSci 2000; 2(1) Article 4 (http://www.aapspharmsci.org/)

26. Gonzales FJ. Pharmacogenetic phenytyping and genotyping. Present status and future potential. Clin Pharmacokinet. 1994;26:59-70.

27. Ball SE, Scatina JA, Sisenwine SF, Fisher GL. The application of in vitro models of drug metabolism and toxicity in drug discovery and drug development. Drug Chem Toxicity. 1995;18:1-28.

28. Guengerich F. The Environmental Genome Project: Functional analysis of polymorphisms. Environment Health Perspect. 1998;106:365-368.

29. Kleyn PW, Vesell ES. Genetic variation as a guide to drug development. Science. 1998;281:1820-1821.

30. Sadee W. Pharmacogenomics. BMJ. 1999;319:1286.

31. Evans WE, Relling MV. Pharmacogenomics: translating functional genomics into rational therapeutics. Science. 1999;286:487-491.

32. Iyer VR, Eisen MB, Ross DT, et al. The transcriptional program in the response of human fibroblasts to serum. Science. 1999;283,83-87.
33. Schachter B. Pharming the Genome. Biomednet [serial online]. October 30, 1998;41.

34. Fluri KG, Fitzpatrick G, Chiem N, Harrison DJ. Integrated capillary electrophoresis devices with an efficient postcolumn reactor in planar quartz and glass chips. Anal Chem. 1996;68:42854290.

35. Jacobson SC, Ramsey SC. Integrated microdevice for DNA restriction fragment analysis. Anal Chem. 1996;68:720-723.

36. Blanchard AP, Friend SH. Cheap DNA arrays-;it's not all smoke and mirrors. Nature Biotech. 1999;17:953.

37. Russo E. Big pharma hedges its bets. The Scientist. 1999;13:1.

38. Poste G. In Bio '98 International Meeting and Exposition 19. New York: RAND Corporation;1999.

39. Weber WW. Pharmacogenetics. New York: Oxford University Press; 1997. 